\title{
The Relation Between the Structure of Abstracts in LIS and Anthropology Journals and Their Rank
}

\author{
Arkadiusz Pulikowski \\ ORCID 0000-0003-1807-8642 \\ Institute of Culture Studies, Faculty of Humanities \\ University of Silesia in Katowice, Poland
}

\begin{abstract}
Purpose/Thesis: The study determines: (1) which of the commonly expected elements of abstracts feature in library and information science (LIS) and anthropology journals; (2) whether there is a relationship between the journal rank as measured by the Impact Factor and the number of components present in the journal's abstracts.

Approach/Methods: The research had two main stages. Firstly, the scope of research was determined by selecting specific disciplines and journals. Secondly, randomly selected abstracts were analyzed to see if the key components were present.

Results and conclusions: The key abstract components (background, purposes, methods, results) do not vary across the journals from both disciplines. In general, the abstracts from journals of higher rank are longer than those from journals of lower rank and have more components present. The results were proven for LIS and anthropology but the pattern may hold true for journals from other disciplines. This requires further research.

Originality/Value: The study extends prior research by correlating the completeness of information included in abstracts with journal rank measured by Impact Factor.
\end{abstract}

Keywords

Anthropology. Journal rank. Library and information science. Structure of abstracts. Structured abstracts. Traditional abstracts.

Received: 2 March 2020. Reviewed: 8 April 2020. Revised: 20 April 2020. Accepted: 14 May 2020.

\section{Introduction}

The abstract is an essential part of a journal article, as well as an important element of more widely understood scientific communication. The abstract is read more often than any other part of the paper it is attached to, as the hosting websites do not restrict the readers' access to it. The abstract is also important because it is indexed by search engines, which affect the article's visibility. It is basing on the abstract that the researchers decide whether to read the full text of an article, which may require further effort or payment. However, not only researchers make decisions on the basis of the abstracts. It concerns journal editors as well. Some papers are rejected without a peer review, judged only by their abstracts (Groves \& Abbasi, 2004) ${ }^{1}$.

\footnotetext{
${ }^{1}$ One of the editors put it this way: "And let us be honest: as readers, we sometimes read only the abstract as well" (Leibovici, 2017).
} 
The word abstract is an umbrella term which covers abstracts written both by the paper's authors and by professional abstractors. It is

a text that reflects the most important information of an existing (primary) text in a form shorter than the original. The importance of information is decided from a pre-defined viewpoint, which enables the abstract to serve informing (informational) goals (Koltay, 2010, 21, 26).

Abstracts can be divided into two types: traditional and structured. Traditional abstracts are written in a single block, and authors have full control over the abstract content. Structured abstracts use distinct, labeled sections (e.g., background, purpose, methods, results, conclusions) to ensure that the information received by the readers is clear and consistently presented. The components distinguished in structured abstracts feature in traditional ones, but they are not labeled. Headings oblige authors to prepare abstracts in a standardized way, which guarantees that no important element is omitted. Components like purpose, methods, results, conclusions are the key elements expected from good abstracts (whether they are traditional or structured). The abstracts' structure is prescribed not only in many journals' guidelines for authors but also in standards: ISO 214:1976 Documentation - Abstracts for publications and documentation (ISO, 1976), ANSI/NISO Z39.14-1997 (2015) Guidelines for Abstracts (ANSI/NISO, 2015).

ANSI/NISO standard (2015) includes another division of abstracts, which is worth mentioning. It distinguishes informative and indicative abstracts. Indicative abstracts are usually written for documents that do not contain information relating to methodology or results, such as editorials, essays, reviews, books, conference proceedings. Informative abstracts are typical for research papers. They state the purpose, methodology, results, and conclusions presented in the original document (ANSI/NISO, 2015, 4).

The subject of this study are both structured and traditional informative abstracts published in journals from the field of library and information science (LIS) and anthropology. The study intends to determine: (1) which commonly expected elements of abstracts are present in LIS and Anthropology journals; (2) whether there is a relationship between the journal rank measured by Impact Factor and the number of components present in the journal's abstracts.

\section{Previous studies}

The research on the structure of abstracts focuses on two major issues: structured abstracts - their applications, types of subheadings used, and advantages over traditional abstracts, and the completeness of the key elements in traditional or, less often, in structured abstracts, within selected journals or disciplines. The pattern of structured abstract subheadings is often used as a criterion for completeness. The same approach will be used in the current study.

Structured abstracts first appeared in medical literature in the mid-1980s, and this is the area where they are most prevalent today (Hartley, 2004). According to Hua et al. (2018), 88\% of top-50 medical journals use structured abstracts. $66 \%$ of them apply IMRaD format (Introduction, Methods, Results and Discussion) and 34\% Highly Structured (HS). The HS format is specific to medicine. The methods section is divided into multiple 
subsections, such as Participants and Interventions. In contrast to the HS format, IMRaD is suitable for non-medical disciplines since it follows the IMRaD structure of scientific research articles (Wu, 2011, 1348) ${ }^{2}$. James Hartley (1998) showed that many authors fail to supply sufficient information for the abstract when only four IMRaD headings are used. Therefore, he proposed distinguishing aims as a separate section. He argued that structured abstracts in journals should contain at least five headings - background, aims, methods, results and conclusions - partly because these headings match the traditional IMRaD format for research articles (Zhang \& Liu, 2011, 572-573). This five-item scheme is used in guidelines for authors in many scientific journals, with some variations of labels' names, as shown below:

- Background/Introduction/Context;

- Purpose/Aim/Objective/Thesis;

- Methods/Approach/Design;

- Results/Findings;

- Conclusions/Implications/Discussion.

The research on completeness of abstracts is often conducted in disciplines where structured abstracts are less common. Its aim is to show deficiencies of traditional single-block abstracts and to encourage implementation of the structured ones. The following two studies inspired the approach taken in the article at hand. Hartley and Betts (2009) evaluated the quality of 100 traditional abstracts published in 53 social science journals from five disciplines: health and old age, schooling, higher education, new technology, academic writing. Most abstracts included information about the aims (92\%), the results (88\%), the methods (84\%), and the conclusions (78\%). The background information was provided in just over half of the abstracts (56\%). Curran (2016) examined abstracts from the top 150 education research. Most authors included statements of aim (89\%) and results (86\%); a smaller group included statements of methods $(73 \%)$; the least mentioned background (60\%) and conclusions (61\%). Only $6 \%$ of the sampled abstracts utilized structured abstracts.

Although the comparison of structured and traditional abstracts is not the main subject of this study, it was an aspect of the research presented. Many studies were devoted to this issue. Hartley summed them up in his articles from 2004 and 2014. Compared with traditional ones, structured abstracts are:

- clearer;

- easier to read;

- easier to search;

- more informative but usually longer as a result;

- more complete in terms of vital elements presence;

- generally welcomed by readers and by authors (Hartley, 2004, 2014).

${ }^{2}$ IMRaD as a format of structure for scientific journals is much older than the one for abstracts. It began to be adopted around the 1940s and became the dominant format for research papers in a majority of leading scientific journals by the late 1970s (Wu, 2011, 1346). 


\section{Methodology}

The study had two main stages. Firstly, its scope was determined by selecting specific disciplines and journals. Secondly, randomly selected abstracts were analyzed to see if the key components were present.

\subsection{Selection of disciplines and journals}

Two disciplines from the field of social sciences ${ }^{3}$ were selected - Library and Information Science (LIS), and Anthropology. The disciplines were chosen from the same research area i.e., social sciences, to make a comparison feasible. It is usually more tempting to compare very contrasting objects, such as LIS and Organic chemistry, to obtain more pronounced results, but in this case the author wanted just the opposite - to examine disciplines with the same roots and see if there are any differences in the construction of the abstracts in the related journals.

The Clarivate Analytics 2018 Journal Citation Report (JCR), SSCI edition (Social Sciences Citation Index) was used to select and compare disciplines and journals. The discipline of LIS was first selected because it is the author's main research area. There are 89 journals listed in JCR under the equivalent category "Information Science and Library Science"; 25 of them are also assigned to other categories. They were removed from the list to make the LIS category more homogenous. Another 12 journals had to be excluded for various reasons, such as absence or inaccessibility of abstracts, absence of English abstracts, or termination of the journal's publishing. As a result, the list was reduced to 52 items. Eventually, it was cut to 50 by removing two journals with the lowest Impact Factor (IF). The ISSN number, publisher's name and IF of each journal were stored in a MS Excel spreadsheet for later processing.

Tab. 1. Comparison of the disciplines selected, based on JCR, 2018, SSCI Edition

\begin{tabular}{|l|c|c|c|}
\hline \multicolumn{1}{|c|}{ JCR category } & $\begin{array}{c}\text { Number of } \\
\text { journals }\end{array}$ & Total cites & $\begin{array}{c}\text { Median Impact } \\
\text { Factor }\end{array}$ \\
\hline $\begin{array}{l}\text { Information Science \& Library } \\
\text { Science }\end{array}$ & 89 & 152878 & 1.265 \\
\hline Anthropology & 90 & 141350 & 1.105 \\
\hline
\end{tabular}

The second discipline was carefully selected. For a comparison with LIS to be feasible, the study targeted a discipline with a similar number of journals indexed in JCR and a similar distribution of IF. The last condition was important for achieving the second research objective (see section 4.2). Several categories (disciplines) with the number of journals close to LIS were examined but anthropology proved to be the best match. After applying the criteria described above, 50 anthropology journals were chosen for further study. The distribution

\footnotetext{
${ }^{3}$ According to OECD field of science and technology classification (OECD, 2007), Anthropology is a sub-discipline of Sociology and LIS is a sub-discipline of Media and communications. Both parent disciplines belong to Social sciences.
} 
of IF was similar, which is indirectly indicated by the value of the Median Impact Factor. Summary information on both disciplines are presented in Table 1; on the distribution of IF - in Figure 1. The list of all journals included in the study is provided in Appendix 1.

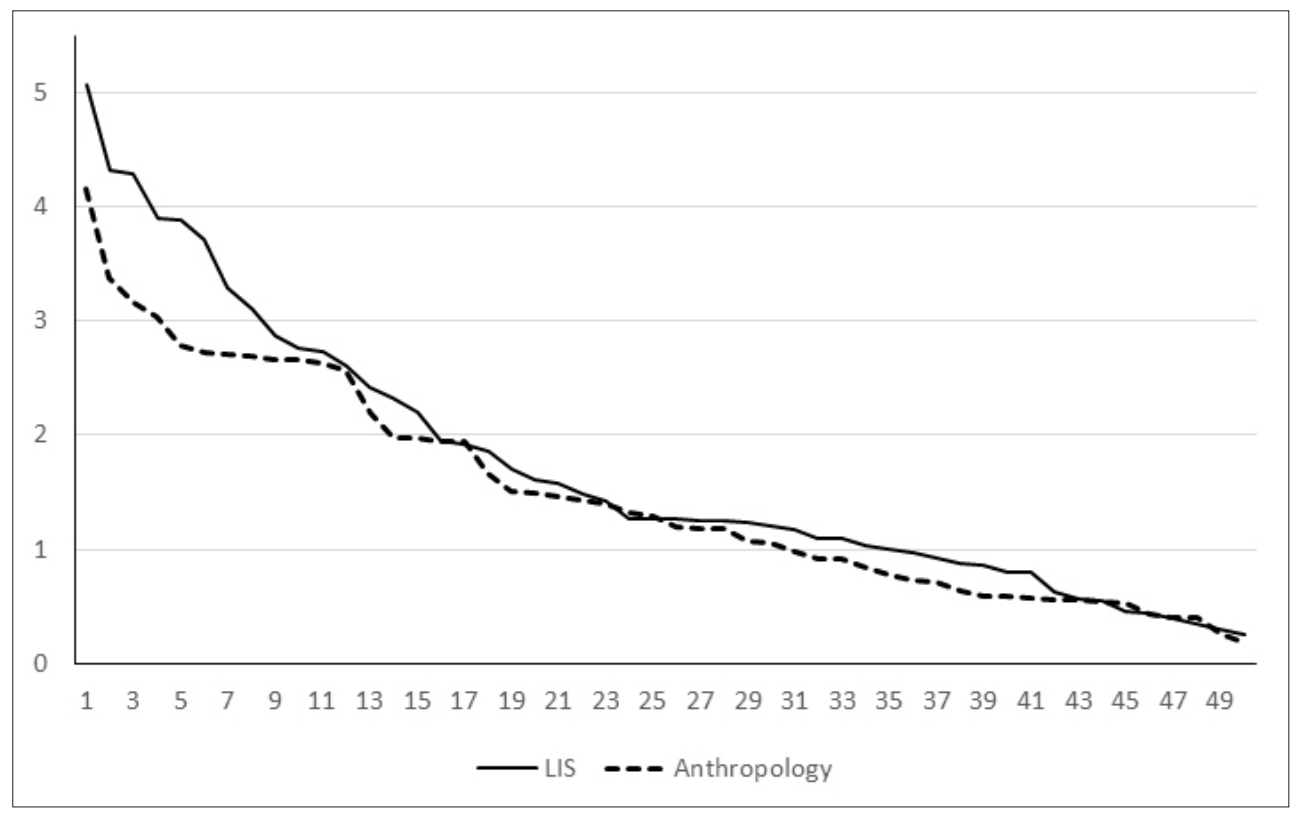

Fig. 1. Distribution of IF among 50 selected journals in LIS and Anthropology

\subsection{Selecting abstracts and coding}

Two abstracts were randomly chosen from one of 2019 issues of each journal selected in the previous stage. Thus determined, the data sample comprised 200 abstracts, 100 per discipline. Only abstracts from regular/original/research papers were taken into account. Special issues were entirely omitted. To make sure that the abstracts came from regular papers they were checked and downloaded not via JCR but directly from the official websites of journal publishers. In some cases, abstracts were written in such a fashion that it was impossible to determine what was the author's own contribution and what of his predecessors. In that case, the next abstract was taken. For the same reason, an entire journal American Ethnologist, had to be excluded.

Each abstract was examined and binary-coded to see if it included basic components: background, purpose, methods, results, and conclusions. Additionally, abstracts including specific section headings were coded as structured. All this information, together with the abstracts themselves, was recorded alongside the previously obtained journals' data. It was important for this research to keep the connection between the abstract and the journal to allow an examination of the relationship between the journals' rank and the abstracts' components.

All coding was done by the author. In order to minimize the number of errors of interpretation similar circumstances, the coding was conducted twice, each time starting from 
LIS abstracts - the discipline better known to the author. In many cases it was difficult to establish if a given statement was sufficient to consider it a proper component and to code it as "1". It was easy with longer paragraphs, but quite often the item sought was represented in the text by a single sentence, or a single clause. A typical example can be seen below.

Sources of drinking water on islands often present critical constraints to human habitation. On Rapa Nui (Easter Island, Chile), there is remarkably little surface fresh water due to the nature of the island's volcanic geology. While several lakes exist in volcanic craters, most rainwater quickly passes into the subsurface and emerges at coastal springs. Nevertheless, the island sustained a relatively large human population for hundreds of years, one that built an impressive array of monumental platforms (ahu) and statues (moai). To understand how Rapanui acquired their scarce fresh water, we review ethnohistoric data from first European arrival (1722) through the mid-twentieth century. Ethnohistoric accounts identify a diversity of freshwater sources and describe various Rapanui freshwater management strategies. Our findings highlight the importance of coastal freshwater seeps and provide much-needed insight into how Rapanui procured this vital and necessary resource (Hixon et al., 2019).

Each of the BPMRC elements was deemed to be present. Following a longer section outlining the background, the highlighted sentence covered both purpose and methods. The next sentence was concerned with the results, and the last one discussed conclusions. The study was flexible when it came to assessing what constituted 'presence' of an element. However, flexibility had its limits. The statement concluding another abstract, „The implications of these findings are discussed" was coded as "0", because it said nothing of substance regarding these 'implications.'

The purpose of an article was not always explicitly stated. Different forms were accepted: thesis statement, thesis hypothesis, subject of study. Each of these forms could be easily transformed to the sentence beginning from: "The purpose of the study was to confirm/ verify/ present/describe....

\section{Study results and discussion}

\subsection{The presence of BPMRC elements in the investigated abstracts}

The results of the first part of the study are presented in Figure 2. As the total number of abstracts per discipline was 100 (50 journals, two abstracts per each), the figures refer to both the number of abstracts and the percentage value. The chart makes the similarity of results for both disciplines immediately visible. The maximum measured difference is only $10 \%$ (for methods). It is also easy to identify the most and least used element of BPMRC. Less than $10 \%$ of abstracts lacked the purpose section and more than $30 \%$ lacked the background section. Other components are within this range. The results are consistent with prior research on abstracts in the social sciences (Hartley \& Betts, 2009; Curran, 2016), even though the methods used here were different.

Thirteen out of 50 LIS journals (26\%) use structured abstracts, and only two $(4 \%)^{4}$ of anthropology. Among these 15 journals:

- five (including the only two from anthropology) are somehow related to medical or biological sciences, which have a long history of structured abstracts usage;

\footnotetext{
${ }^{4}$ In Appendix 1 the titles of journals with structured abstracts are underlined.
} 
- nine are published by Emerald, which requires structured abstracts from all its journals;

- only one uses structured abstracts without any external determinants - Information Research. An International Electronic Journal.

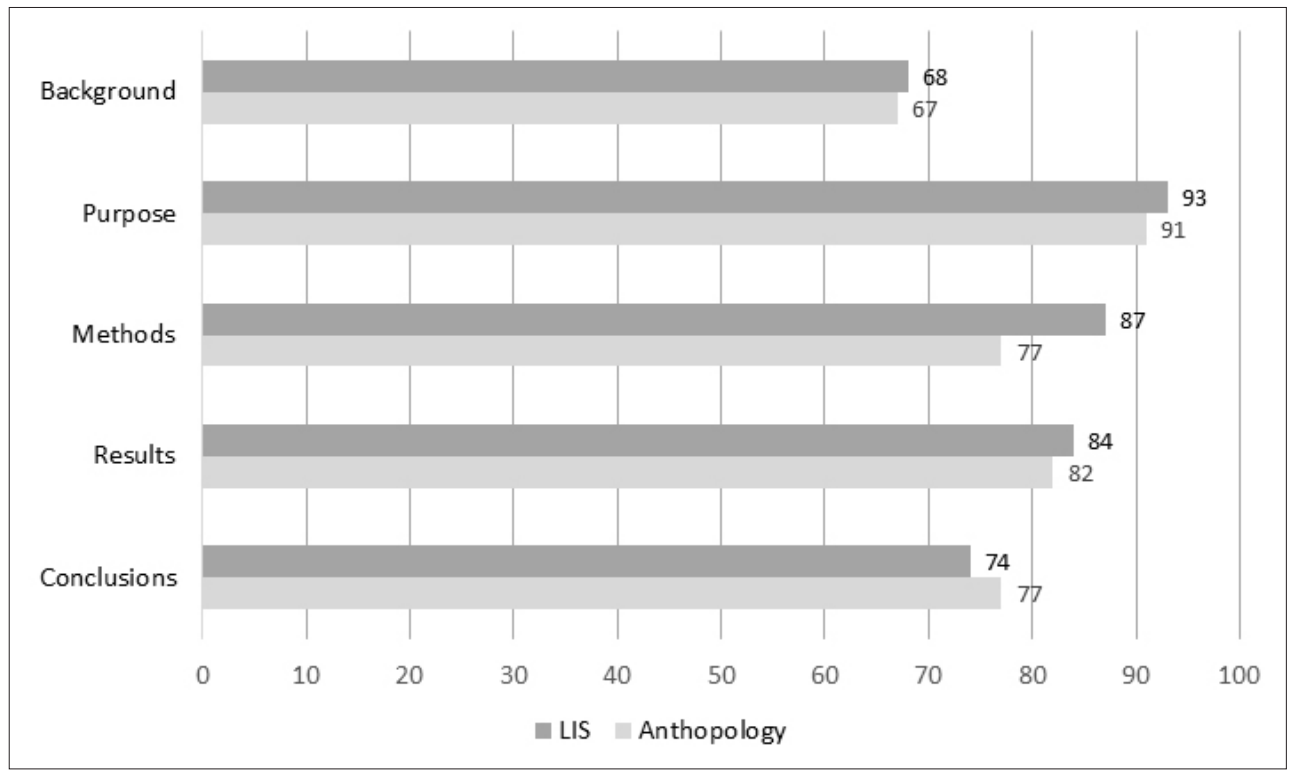

Fig. 2. The presence of the BPMRC components in the analyzed abstracts

Structured abstracts are complete by default. All distinguished sections should be provided by authors. It means that all 30 abstracts from the 15 journals should have $100 \%$ components present. It is true with one exception - the background element, which is not always included in the required structure (e.g. in Emerald journals). However, the lack of this element in the structure does not necessarily mean that it will not appear. In such a situation many authors place background information at the beginning of the purpose component.

Since as many as $26 \%$ of LIS journals have structured abstracts ensuring high completeness, it may seem, that if they were excluded out of the 50, the BPMRC values for the discipline would be much lower compared to the data presented in Figure 2. After recalculating, the figures would change as follows: background $68 \rightarrow 70[+2]$, purpose $93 \rightarrow 91[-2]$, methods $87 \rightarrow 82[-5]$, results $84 \rightarrow 78[-6]$, conclusions $74 \rightarrow 66[-8]$. The difference is less than could be expected. The values remain comparable to anthropology results. The background component increased for the reasons mentioned above.

The background section is problematic. It is no accident that some publishers do not demand it (e.g. Elsevier, Emerald). It is difficult to write a short background, which is by default descriptive. As a consequence, the abstract gets longer, what makes it harder to scan. In the case of structured abstracts, a reader already familiar with the subject may skip the background component. However, structured abstracts tend to be much longer 
than traditional ones (Hartley, 2004; Kim, 2018). This is seen as a drawback, which is why, to make the abstract shorter, the background element is excluded by some publishers. It is reasonable, because the informative value of the background section is small - it covers issues that are already known. Outlining the background in a traditional abstract might prove even more challenging. It often takes up half of the abstract, as in the example from section 3.2. This prevents scanning for key information and negatively affects the size of other elements essential for the readers.

Among all 100 journals from both LIS and anthropology, 61 (61\%) were published by the major publishing groups: Wiley - 16, Taylor \& Francis - 11, Elsevier - 10, Emerald - 9, Springer - 6, SAGE - 6, Walter De Gruyter - 2, IGI Global - 1. Other journals (39\%) were published by universities and scientific societies. With the information about the journal publishers recorded during the data collection process, it was possible to obtain results regarding the presence of BPMRC elements in their journals' abstracts. Four publishers with the highest number of journals were compared in Table 2. The others had too few journals and, consequently, too few abstracts to make the comparison reliable.

Tab. 2. The relation between the publisher and the BPMRC components

\begin{tabular}{|l|c|c|c|}
\hline \multicolumn{1}{|c|}{ Publisher } & Number of journals & Number of abstracts & BPMRC [\%] \\
\hline Elsevier & 10 & 20 & 91 \\
\hline Emerald & 9 & 18 & 91 \\
\hline Wiley & 16 & 32 & 84 \\
\hline Taylor \& Francis & 11 & 22 & 77 \\
\hline
\end{tabular}

The BPMRC column indicates the percentage of all the components found in the abstracts from the publishers' journals. Emerald, with its structured abstracts ensuring high completeness, has the same percentage of BPMRC elements as Elsevier, which requires traditional abstracts from the authors. Elsevier's high score would still have to be confirmed using a larger sample ${ }^{5}$ but it seems that it is possible to ensure high completeness of BPM$\mathrm{RC}$ elements without structured abstracts usage. It is worth noting that Elsevier demands that abstracts include the purpose, results and conclusions in the guidelines for authors, while Wiley and Taylor \& Francis do not mention anything about the abstract's content. This may at least partially explain Elsevier's higher score.

\subsection{Relationship between the journal rank and the number of BPMRC elements present in their abstracts}

It was mentioned in section 3.1 that the distribution of Impact Factor for both LIS and anthropology journals was similar. It was important to examine the relationship between the journal rank and the number of BPMRC elements present in their abstracts in two different disciplines.

\footnotetext{
${ }^{5}$ The author examined additional randomly chosen abstracts from other Elsevier journals from the social science area. They also proved the high completeness of the BPMRC elements. However, it was just a reconnaissance and further research is needed.
} 
The CiteScore from Scopus was considered as an alternative to the Impact Factor. These two journal metrics offer comparable information regarding prestige of a journal, as Zbigniew Osiński (2019) has recently established for LIS discipline. The Impact Factor was chosen because it had been used for longer, and as a result, its usage was wider.

It was expected that the abstracts from journals of higher rank would have more BPMRC components present than journals of lower rank. To verify this assumption 10 journals of the highest rank (1-10) were compared with 10 journals of the lowest rank (41-50). Table 3 shows detailed comparison of BPMRC elements for journals with the highest and lowest ranks. The binary coding for each abstract is written in the BPMRC order. Without any calculation the difference is clearly visible - the number of absent components (the "0"s), for journals of the 41-50 rank, outnumbers the number of absent components in the journals of the 1-10 rank, which confirms the assumption mentioned above.

Tab. 3. Detailed comparison of BPMRC elements for journals with the highest and lowest ranks

\begin{tabular}{|c|c|c|c|c|c|c|c|c|c|c|c|c|c|c|c|c|c|c|c|c|}
\hline \multirow{3}{*}{$\begin{array}{c}\begin{array}{c}\text { Jour. } \\
\text { rank }\end{array} \\
1 .\end{array}$} & \multicolumn{10}{|c|}{ LIS } & \multicolumn{10}{|c|}{ Anthropology } \\
\hline & \multicolumn{5}{|c|}{ Abstract 1} & \multicolumn{5}{|c|}{ Abstract 2} & \multicolumn{5}{|c|}{ Abstract 1} & \multicolumn{5}{|c|}{ Abstract 2} \\
\hline & 1 & 1 & 1 & 1 & 1 & 1 & 1 & 1 & 1 & 1 & 1 & 1 & 1 & 1 & 1 & 1 & 1 & 1 & 0 & 1 \\
\hline 2. & 1 & 1 & 1 & 1 & 1 & 1 & 1 & 1 & 1 & 1 & 1 & 1 & 1 & 1 & 1 & 1 & 1 & 1 & 1 & 1 \\
\hline 3. & 1 & 1 & 1 & 1 & 1 & 0 & 1 & 1 & 1 & 1 & 1 & 1 & 1 & 1 & 1 & 1 & 1 & 1 & 1 & 0 \\
\hline 4. & 1 & 1 & 1 & 1 & 1 & 1 & 1 & 1 & 1 & 0 & 1 & 1 & 0 & 1 & 1 & 1 & 1 & 1 & 1 & 1 \\
\hline 5. & 1 & 1 & 1 & 1 & 1 & 1 & 1 & 1 & 1 & 1 & 1 & 1 & 1 & 1 & 1 & 1 & 1 & 1 & 1 & 1 \\
\hline 6. & 1 & 1 & 1 & 0 & 0 & 1 & 1 & 1 & 1 & 1 & 0 & 1 & 1 & 1 & 1 & 1 & 1 & 1 & 1 & 1 \\
\hline 7. & 0 & 1 & 1 & 1 & 1 & 1 & 1 & 1 & 1 & 1 & 1 & 1 & 1 & 1 & 1 & 1 & 1 & 1 & 1 & 1 \\
\hline 8. & 0 & 1 & 1 & 1 & 1 & 1 & 1 & 1 & 1 & 1 & 1 & 1 & 1 & 1 & 1 & 1 & 1 & 0 & 0 & 1 \\
\hline 9. & 1 & 1 & 1 & 1 & 1 & 0 & 1 & 1 & 1 & 1 & 0 & 1 & 1 & 1 & 0 & 0 & 1 & 0 & 1 & 0 \\
\hline 10. & 0 & 1 & 1 & 1 & 0 & 1 & 1 & 1 & 1 & 1 & 1 & 1 & 1 & 1 & 1 & 0 & 1 & 1 & 1 & 1 \\
\hline$\ldots$ & & & & & & & & & & & & & & & & & & & & \\
\hline 41. & 1 & 1 & 1 & 1 & 1 & 1 & 1 & 1 & 1 & 1 & 0 & 0 & 1 & 1 & 1 & 1 & 1 & 1 & 1 & 1 \\
\hline 42. & 1 & 0 & 0 & 0 & 0 & 0 & 1 & 1 & 0 & 0 & 1 & 1 & 0 & 1 & 0 & 1 & 1 & 1 & 1 & 1 \\
\hline 43. & 1 & 1 & 1 & 1 & 1 & 1 & 1 & 1 & 1 & 1 & 1 & 0 & 1 & 1 & 1 & 1 & 1 & 1 & 0 & 0 \\
\hline 44. & 1 & 1 & 1 & 1 & 1 & 1 & 1 & 0 & 1 & 1 & 0 & 1 & 0 & 1 & 1 & 1 & 1 & 0 & 0 & 1 \\
\hline 45. & 0 & 1 & 1 & 1 & 1 & 1 & 1 & 0 & 0 & 1 & 0 & 1 & 1 & 1 & 0 & 1 & 1 & 0 & 1 & 1 \\
\hline 46. & 1 & 1 & 0 & 0 & 0 & 1 & 1 & 0 & 0 & 0 & 0 & 1 & 0 & 1 & 1 & 0 & 1 & 0 & 1 & 0 \\
\hline 47. & 1 & 1 & 0 & 0 & 1 & 1 & 0 & 0 & 0 & 0 & 0 & 1 & 0 & 0 & 0 & 0 & 1 & 0 & 1 & 1 \\
\hline 48. & 1 & 1 & 0 & 1 & 1 & 0 & 1 & 1 & 1 & 1 & 0 & 1 & 1 & 1 & 0 & 0 & 1 & 1 & 1 & 1 \\
\hline 49. & 1 & 1 & 1 & 1 & 0 & 0 & 1 & 1 & 1 & 1 & 1 & 0 & 0 & 1 & 1 & 0 & 1 & 1 & 0 & 1 \\
\hline 50. & 1 & 1 & 1 & 1 & 0 & 1 & 1 & 0 & 0 & 0 & 1 & 1 & 0 & 1 & 0 & 0 & 1 & 1 & 1 & 1 \\
\hline
\end{tabular}

The figures from Table 3 were summarized in Table 4. The difference in completeness of all BPMRC elements for journals with the highest and lowest ranks is $22 \%$ for LIS and 23\% for anthropology. The difference is substantial, and it is very similar in both disciplines, which adds to the obtained results' credibility. Extending the ranges of compared journal 
ranks from 1-10 and 41-50, through intermediate values (e.g. 1-15 and 46-50), to the maximum 1-25 and 26-50, gradually decreases the difference in the completeness of the two groups. It reaches the minimal values of $11 \%$ for LIS and $10 \%$ for Anthropology when the proportion is half and half.

Along with information on BPMRC completeness, Table 4 provides information on the average number of words in the abstract for a given journal rank range. Intuition suggests that abstracts with higher completeness (rank 1-10) should be longer than the ones with lower (rank 41-50). These assumptions are confirmed by the data presented in Table 4 . In the case of LIS the difference is 30 words, while in anthropology 20. The sample size -20 abstracts per discipline's rank range is far too little to compare the figures, but the overall difference in the length of abstracts between the groups of journals with the highest and lowest ranks is undeniable.

Tab. 4. The relationship between the journal rank, BPMRC completeness and the average number of words per abstract

\begin{tabular}{|c|c|c|c|c|}
\hline \multirow{2}{*}{$\begin{array}{c}\text { Journal } \\
\text { rank range }\end{array}$} & \multicolumn{2}{|c|}{ LIS } & \multicolumn{2}{c|}{ Anthropology } \\
\cline { 2 - 5 } & BPMRC [\%] & Words per abstract & BPMRC [\%] & Words per abstract \\
\hline $1-10$ & 91 & 205 & 88 & 189 \\
\hline $41-50$ & 69 & 175 & 65 & 169 \\
\hline Difference & 22 & 30 & 23 & 20 \\
\hline
\end{tabular}

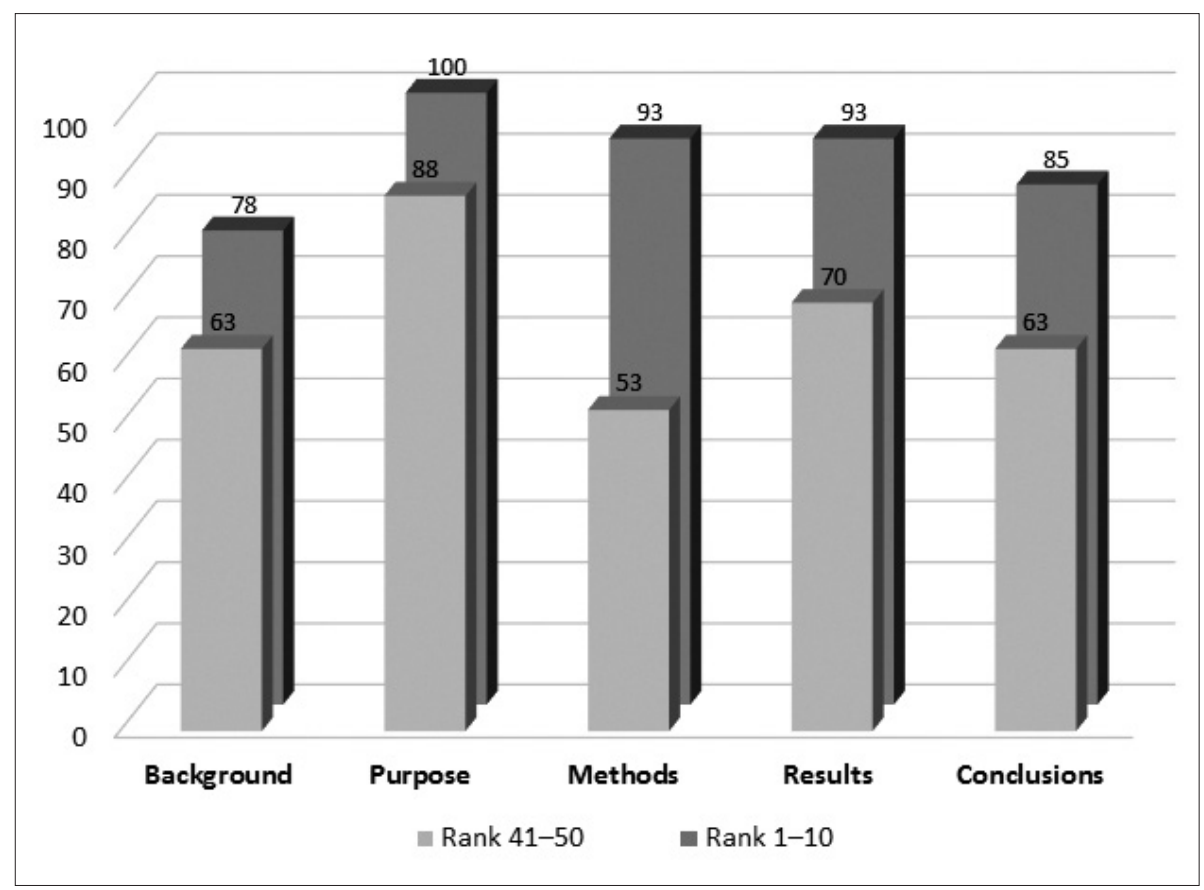

Fig. 3. The relation between the journal rank and the completeness of BPMRC elements [\%] 
In Figure 3 the data is shown within categories designated by BPMRC components. Since LIS and anthropology are very similar in this respect (see Fig. 2), the information from the disciplines was combined to increase the sample size from 20 to 40 abstracts in both journal rank ranges.

The average decrease of completeness $-22 / 23 \%$ reported in Table 4 is not evenly distributed within BPMRC categories, as shown in Figure 3. It is the smallest for the purpose section $-12 \%$ and the largest for the methods section $-40 \%$. The differences for background, results and conclusions are moderate $-15 \%, 23 \%, 22 \%$ accordingly.

\section{Conclusion}

The first part of the results, presented in section 4.1, confirms previous research on abstracts in the social sciences. Library and information science and anthropology proved to be similar in terms of the presence of commonly expected elements of abstracts - background, purposes, methods, results, conclusions. The most often included component is purpose and the least is background.

The second part of the results, presented in section 4.2, extends prior research by correlating the completeness of information included in abstracts with journal rank measured by Impact Factor. In general, the abstracts from journals of higher rank have more components present than those from journals of lower rank. Additionally, it was found that the abstracts from journals of higher rank tend to be longer than the ones from journals of lower rank. The results were proven for LIS and anthropology. Further research is needed to generalize the results to other disciplines and to interpret them.

The study revealed interesting patterns of the usage of structured abstracts. $26 \%$ of the LIS journals examined used such abstracts; only $4 \%$ of the anthropology journals. Although the completeness of structured abstracts is very high, excluding them all in calculation for LIS resulted in much smaller decrease of completeness than expected - both disciplines remained comparable. It means that unstructured abstracts of other journals must have been good enough to keep the results for LIS high. Similar conclusions can be drawn from the comparison of two publishing groups. Emerald, with structured abstracts in all journals, had the same percentage of BPMRC elements as Elsevier, which requires traditional abstracts from the authors. Keeping in mind that further research is necessary on a larger sample to confirm the results, this comparison also supports the hypothesis that it is possible to ensure high completeness of BPMRC elements without structured abstracts usage.

The results may suggest that traditional single block abstracts can well replace the structured ones. This is not the case. The study is concerned with only one aspect - completeness of the key elements of abstracts and only for the high-rank journals or the publishers with high-quality control. The clear structure of structured abstracts makes them easier to read, enabling quick scanning. The length of individual components is better balanced and the order of the components is always the same. Accordingly, journals introduce or maintain structured abstracts. This may be particularly beneficial for journals of lower rank, which want to improve the quality of their abstracts and provide effective means for assessing the relevance of their articles' content. Obviously, this alone will not improve the journals' rank but it may be a preliminary step in this direction. 


\section{Appendix 1}

\section{The list of journals included in the study based on JCR, 2018, SSCI Editon}

The names of journals requiring structured abstracts were underlined.

\begin{tabular}{|c|c|c|c|c|}
\hline Rank & LIS journal title & IF & Anthropology journal title & IF \\
\hline 1. & $\begin{array}{l}\text { International Journal of Informa- } \\
\text { tion Management }\end{array}$ & 5.063 & Cultural Anthropology & 4.154 \\
\hline 2. & $\begin{array}{l}\text { Government Information Quar- } \\
\text { terly }\end{array}$ & 4.311 & Evolutionary Anthropology & 3.375 \\
\hline 3. & $\begin{array}{l}\text { Journal of the American Medical } \\
\text { Informatics Association }\end{array}$ & 4.292 & Journal of Human Evolution & 3.155 \\
\hline 4. & $\begin{array}{l}\text { Information Processing \& Mana- } \\
\text { gement }\end{array}$ & 3.892 & Journal of Archaeological Science & 3.030 \\
\hline 5. & Journal of Informetrics & 3.879 & Current Anthropology & 2.787 \\
\hline 6. & Telematics and Informatics & 3.714 & $\begin{array}{l}\text { Journal of Anthropological Scien- } \\
\text { ces }\end{array}$ & 2.731 \\
\hline 7. & Information Systems Journal & 3.286 & American Anthropologist & 2.709 \\
\hline 8. & $\begin{array}{l}\text { Journal of the Association for } \\
\text { Information Systems }\end{array}$ & 3.103 & Annual Review of Anthropology & 2.698 \\
\hline 9. & Research Evaluation & 2.875 & Journal of Archaeological Research & 2.667 \\
\hline 10. & Scientometrics & 2.770 & $\begin{array}{l}\text { American Journal of Physical } \\
\text { Anthropology }\end{array}$ & 2.662 \\
\hline 11. & $\begin{array}{l}\text { Journal of the Association for In- } \\
\text { formation Science and Technology }\end{array}$ & 2.738 & Journal of World Prehistory & 2.632 \\
\hline 12. & $\begin{array}{l}\text { European Journal of Information } \\
\text { Systems }\end{array}$ & 2.603 & $\begin{array}{l}\text { Journal of Archaeological Method } \\
\text { and theory }\end{array}$ & 2.571 \\
\hline 13. & $\begin{array}{l}\text { Journal of the Medical Library } \\
\text { Association }\end{array}$ & 2.420 & Australian Archaeology & 2.188 \\
\hline 14. & Journal of Information Science & 2.327 & $\begin{array}{l}\text { Archaeological and Anthropologi- } \\
\text { cal Sciences }\end{array}$ & 1.978 \\
\hline 15. & Learned Publishing & 2.200 & $\begin{array}{l}\text { Journal of the Royal Anthropologi- } \\
\text { cal Institute }\end{array}$ & 1.972 \\
\hline 16. & College \& Research Libraries & 1.946 & Social Anthropology & 1.942 \\
\hline 17. & Online Information Review & 1.928 & $\begin{array}{l}\text { Journal of Anthropological Archa- } \\
\text { eology }\end{array}$ & 1.939 \\
\hline 18. & Information Society & 1.860 & American Antiquity & 1.671 \\
\hline 19. & $\begin{array}{l}\text { Aslib Journal of Information Ma- } \\
\text { nagement }\end{array}$ & 1.702 & Anthropological theory & 1.509 \\
\hline
\end{tabular}




\begin{tabular}{|c|c|c|c|c|}
\hline 20. & Journal of Academic Librarianship & 1.608 & Ethnos & 1.494 \\
\hline 21. & Journal of Documentation & 1.573 & Antiquity & 1.469 \\
\hline 22. & $\begin{array}{l}\text { Information Technology for Deve- } \\
\text { lopment }\end{array}$ & 1.493 & $\begin{array}{l}\text { American Journal of Human } \\
\text { Biology }\end{array}$ & 1.438 \\
\hline 23. & $\begin{array}{l}\text { Library \& Information Science } \\
\text { Research }\end{array}$ & 1.425 & African Archaeological Review & 1.404 \\
\hline 24. & Journal of Scholarly Publishing & 1.270 & Journal of Social Archaeology & 1.323 \\
\hline 25. & Information Development & 1.265 & Archaeology in Oceania & 1.286 \\
\hline 26. & Information Technology \& People & 1.263 & Journal of Ethnobiology & 1.195 \\
\hline 27. & Library Hi Tech & 1.256 & Lithic Technology & 1.188 \\
\hline 28. & $\underline{\text { Reference Services Review }}$ & 1.250 & $\begin{array}{l}\text { International Journal of Osteoar- } \\
\text { chaeology }\end{array}$ & 1.180 \\
\hline 29. & Library Quarterly & 1.240 & $\begin{array}{l}\text { PoLAR: Political and Legal Anth- } \\
\text { ropology Review }\end{array}$ & 1.080 \\
\hline 30. & $\begin{array}{l}\text { Journal of Librarianship and Infor- } \\
\text { mation Science }\end{array}$ & 1.203 & Human Biology & 1.061 \\
\hline 31. & $\begin{array}{l}\text { Health Information and Libraries } \\
\text { Lournal }\end{array}$ & 1.179 & Latin American Antiquity & 0.983 \\
\hline 32. & $\begin{array}{l}\text { Data Base for Advances In Infor- } \\
\text { mation Systems }\end{array}$ & 1.103 & Anthropological Quarterly & 0.924 \\
\hline 33. & $\begin{array}{l}\text { Journal of Global Information } \\
\text { Management }\end{array}$ & 1.098 & Critique of Anthropology & 0.911 \\
\hline 34. & Portal: Libraries and the Academy & 1.037 & Anthropological forum & 0.833 \\
\hline 35. & $\begin{array}{l}\text { Malaysian Journal of Library \& } \\
\text { Information Science }\end{array}$ & 1.000 & $\begin{array}{l}\text { HOMO: Journal of Comparative } \\
\text { Human Biology }\end{array}$ & 0.780 \\
\hline 36. & Knowledge Organization & 0.979 & $\begin{array}{l}\text { Australian Journal of Anthropo- } \\
\text { logy }\end{array}$ & 0.727 \\
\hline 37. & $\begin{array}{l}\text { Journal of Global Information } \\
\text { Technology Management }\end{array}$ & 0.923 & Anthropology Southern Africa & 0.714 \\
\hline 38. & Electronic Library & 0.886 & $\begin{array}{l}\text { Journal of Anthropological Rese- } \\
\text { arch }\end{array}$ & 0.639 \\
\hline 39. & $\begin{array}{l}\text { Program: Electronic Library and } \\
\text { Information Systems } \\
\text { Since 2018: Data Technologies and } \\
\underline{\text { Applications }}\end{array}$ & 0.868 & $\begin{array}{l}\text { Journal of Latin American and } \\
\text { Caribbean Anthropology }\end{array}$ & 0.588 \\
\hline 40. & $\begin{array}{l}\text { Information Technology and } \\
\text { Libraries }\end{array}$ & 0.800 & Social Analysis & 0.586 \\
\hline 41. & $\begin{array}{l}\text { Information Research: an Interna- } \\
\text { tional Electronic Journal }\end{array}$ & 0.799 & Anthropologischer Anzeiger & 0.577 \\
\hline 42. & Library Trends & 0.627 & Journal of the Polynesian Society & 0.563 \\
\hline
\end{tabular}




\begin{tabular}{|c|l|c|l|c|}
\hline 43. & $\begin{array}{l}\text { Interlending \& Document Supply } \\
\text { Since 2017: Information Discovery } \\
\text { and Delivery }\end{array}$ & 0.563 & Anthropozoologica & 0.560 \\
\hline 44. & LIBRI & 0.553 & $\begin{array}{l}\text { Bijdragen Tot De Taal - Land - En } \\
\text { Volkenkunde }\end{array}$ & 0.548 \\
\hline 45. & $\begin{array}{l}\text { Library Resources \& Technical } \\
\text { Services }\end{array}$ & 0.459 & Arctic Anthropology & 0.531 \\
\hline 46. & $\begin{array}{l}\text { Reference \& User Services Quar- } \\
\text { terly }\end{array}$ & 0.444 & $\begin{array}{l}\text { Asia Pacific Journal of Anthropo- } \\
\text { logy }\end{array}$ & 0.432 \\
\hline 47. & $\begin{array}{l}\text { Restaurator: International Journal } \\
\text { for the Preservation of Library and } \\
\text { Archival Material }\end{array}$ & 0.394 & Australian Aboriginal Studies & 0.400 \\
\hline 48. & $\begin{array}{l}\text { Journal of the Australian Library } \\
\text { and Information Association }\end{array}$ & 0.348 & Romani Studies & 0.400 \\
\hline 49. & Serials Review & 0.311 & Oceania & 0.270 \\
\hline 50. & $\begin{array}{l}\text { Canadian Journal of Information } \\
\text { and Library Science }\end{array}$ & 0.258 & Anthropological Notebooks & 0.182 \\
\hline
\end{tabular}

\section{References}

ANSI/NISO Z39.14-1997 (2015). Guidelines for Abstracts [online]. National Information Standards Organization, [13.05.2020], https://www.niso.org/publications/ansiniso-z3914-1997-r2015-guidelines-abstracts

Curran, F. C. (2016). The State of Abstracts in Educational Research. AERA Open [online], 2(3), https://doi.org/10.1177/2332858416650168

Groves T., Abbasi K. (2004). Screening Research Papers by Reading Abstracts. BMJ, 329, 470-471, https://doi.org/10.1136/bmj.329.7464.470

Hartley, J. (1998). Headings in Structured Abstracts. British Journal of Psychiatry, 173(02), 173-188, https://doi.org/10.1192/bjp.173.2.178a

Hartley, J. (2004). Current Findings from Research on Structured Abstracts. Journal of the Medical Library Association [online], 92(3), 368-371, [13.05.2020], https://www.ncbi.nlm.nih.gov/pmc/ articles/PMC442180/

Hartley, J., Betts, L. (2009). Common Weaknesses in Traditional Abstracts in the Social Sciences. Journal of the American Society for Information Science and Technology, 60(10), 2010-2018, https:// doi.org/10.1002/asi.21102

Hartley, J. (2014). Current Findings from Research on Structured Abstracts: An Update. Journal of the Medical Library Association [online], 102(3), 146-148, https://doi.org/10.3163/15365050.102.3.002

Hixon, S. W., DiNapoli, R. J., Lipo, C. P., Hunt, T. L. (2019). The Ethnohistory of Freshwater Use on Rapa Nui (Easter Island, Chile). Journal of the Polynesian Society, 128(2), 163-189, https://doi. org/10.15286/jps.128.2.163-189

Hua, F., Walsh, T., Glenny, A. M., Worthington, H. (2018). Structure Formats of Randomised Controlled Trial Abstracts: A Cross-Sectional Analysis of Their Current Usage and Association with Methodology Reporting. BMC Medical Research Methodology [online], 18(1), 6, https://doi. org/10.1186/s12874-017-0469-3 
ISO (1976). Documentation - Abstracts for Publications and Documentation [online]. International Organization for Standardization, [13.05.2020], https://www.iso.org/standard/4084.html

Kim, E. (2018). The Lengths of LIS Journal Abstracts: A Comparison of Structured Abstracts and Traditional [preprint]. Journal of LISSASPAC JAPAN, 1(2), 46-49.

Koltay, T. (2010). Abstracts and Abstracting: A Genre and Set of Skills for the Twenty-First Century. Oxford: Chandos Publishing.

Leibovici, L. (2017). Structured Abstracts for Narrative Reviews. Clinical Microbiology and Infection [online], 23(7), 423, https://doi.org/10.1016/j.cmi.2016.10.027

OECD (2007). Revised Field of Science and Technology (FOS) Classification on the Frascati Manual [online].Organization for Economic Cooperation and Development, [13.05.2020], http://www. oecd.org/dataoecd/36/44/38235147.pdf

Osiński, Z. (2019). The Usefulness of Data from Web of Science and Scopus Databases for Analyzing the State of a Scientific Discipline. The Case of Library and Information Science. Zagadnienia Informacji Naukowej - Studia Informacyjne [online], 57(2A), 45-93, https://doi.org/10.36702/zin.469

Wu, J. (2011). Improving the Writing of Research Papers: IMRAD and Beyond. Landscape Ecology [online], 26, 1345-1349, https://doi.org/10.1007/s10980-011-9674-3

Zhang, C., Liu, X. (2011). Review of James Hartley's Research on Structured Abstracts. Journal of Information Science [online], 37(6), 570-576, https://doi.org/10.1177/0165551511420217

\title{
Struktura abstraktów w czasopismach z zakresu informacji naukowej i bibiliotekoznawstwa oraz antropologii w relacji do rangi tych czasopism
}

\begin{abstract}
Abstrakt
Cel/Teza: Celem badania było określenie: (1) które z kluczowych elementów abstraktów są obecne w czasopismach z zakresu bibliotekoznawstwa i informacji naukowej oraz antropologii, a także (2) czy istnieje związek pomiędzy rangą czasopisma mierzoną za pomocą wskaźnika cytowań (Impact Factor) a liczbą elementów obecnych w jego abstraktach.

Koncepcja/Metody badań: Badanie składało się z dwóch etapów. Pierwszy, obejmujący wybór dyscyplin i czasopism, wyznaczył zakres prowadzonych działań. Drugi etap polegał na analizie losowo wybranych abstraktów z czasopism pod kątem obecności kluczowych elementów.

Wyniki i wnioski: Bibliotekoznawstwo i informacja naukowa oraz antropologia okazały się podobne pod względem obecności kluczowych komponentów w abstraktach - tła, celów, metod oraz wyników. Abstrakty z czasopism o wyższej randze zawierają więcej elementów i są dłuższe niż te z czasopism o niższej randze. Wyniki zostały potwierdzone dla bibliotekoznawstwa i informacji naukowej oraz antropologii, ale mogą być także prawdziwe dla innych dyscyplin - jako ogólna zasada. Wymaga to dalszych badań.

Oryginalność/Wartość poznawcza: Badanie poszerza dotychczasową wiedzę na temat abstraktów o korelację kompletności zawartych w nich informacji z rangą czasopisma, w których abstrakty są publikowane.
\end{abstract}

\section{Słowa kluczowe}

Abstrakt tradycyjny. Abstrakt ustrukturyzowany. Antropologia. Informacja naukowa i bibliotekoznawstwo. Ranga czasopisma. Struktura abstraktu. 
ARKADIUSZ PULIKOWSKI, PhD, is Associate Professor at the Institute of Culture Studies at the University of Silesia in Katowice. His main research areas are information seeking behavior and information retrieval. His most important recent publication is a monograph Modelowanie procesu wyszukiwania informacji naukowej. Strategie i interakcje (2018).

Contact to the Author:

arkadiusz.pulikowski@us.edu.pl

Institute of Culture Studies

Faculty of Humanities

University of Silesia in Katowice

pl. Sejmu Ślaskiego 1

40-032 Katowice, Poland 